The Influence of Implementing the Internal Corporate Governance .....

Dr. Ehab Lotfy AbdElaal Abied \& Dr. Hassan Mahmoud Aly Khalil

\title{
The Influence of Implementing the Internal Corporate Governance on the Efficiency of Managing the Working Capital for Companies Listed in the Egyptian Stock Exchange
}

\author{
Dr. Ehab Lotfy AbdElaal Abied \\ Higher Institute of Administrative Sciences Beni Suwayf \\ Imam Abdulrahman Bin Faisal University, KSA \\ Dr. Hassan Mahmoud Aly Khalil \\ PhD in Business Administration
}

\section{Preliminary Study:}

The good administration of the working capital is the main request for the companies because if the working capital is administered correctly then this promotes the company's profitability and liquidity position. In contrast, in case of not managing the working capital efficiently through the allocation of less or more than that required then this reduces the short-term investment interest in particular the management efficiency. On the other hand, if the capital was allocated more than that required, then the company may not benefit from the investment opportunities or it may be subjected to short-term liquidity crisis (Fiador 2016).

The study by (Dittmar and Mahrt-Smith 2007) reached the conclusion that the good corporate governance is the shareholders' defense against the inefficient use of the company's assets by the managers. The corporate governance can control the bad behavior of the management where the research attempted to promote the relationship between the corporate governance and the efficiency of the financial decision-making processes for the companies (Fiador 2016) (Mardnly, Mouselli et al. 2018) (Grassa, Chakroun et al. 2018) (Ahmad, Ahmed et al. 2018). 
The Influence of Implementing the Internal Corporate Governance .....

Dr. Ehab Lotfy AbdElaal Abied \& Dr. Hassan Mahmoud Aly Khalil

But there is a relative scarcity of studies which link between the corporate governance and the efficiency of managing the working capital especially those who studied the influence of the corporate governance on the Cash Conversion Cycle from the companies (Gill and Biger 2013) (Gill and Shah 2012) where these studies reached governing practices which work on improving the efficiency of managing the working capital.

The corporate governance mechanisms were designed to protect the worries of the managers and the shareholders where these mechanisms work on building a good institutional culture where the management is forced to behave in a way which promotes the value of the shareholders monies. It also assures the effective management of the company resources (Kavulya 2012). The decisions related to the effective management of the working capital are considered as a strategy by its nature and consequently, an important feature for managing the companies is promoting the working capital (Kamau and Basweti 2013).

Therefore, this research aims at studying the influence of the internal corporate governance mechanisms on the efficiency of managing the working capital in the Egyptian Stock Exchange.

\section{Theoretical Framework:}

The current research discussed the influence of the internal corporate governance on the efficiency of managing the working capitals. This item is presented through:

\section{(1) Corporate Governance:}

Nowadays, the corporate governance became an international subject because of the corporate globalization. The practical corporate governance is considered the process through which the organizations can be directed and controlled. This means that the corporate governance includes the authority, supervision, leadership, direction and monitoring which are 
The Influence of Implementing the Internal Corporate Governance .....

Dr. Ehab Lotfy AbdElaal Abied \& Dr. Hassan Mahmoud Aly Khalil practiced in the process of managing the organizations(Achchuthan and Rajendran 2013).

The principle of governance spread quickly in various parts of the world but with some main variations because the conditions vary from one country to another. There are the following two methodologies for corporate governance: Agency Theory and the Stewardship Theory $(\operatorname{Rad} 2014)$.

Both Mulili \& Wong, 2011 define the Agency Theory as the separation between the control and the ownership through the management of the company by professional managers on behalf of its owners. Whereas the Stewardship Theory suggests that the company's board of directors and its executive manager work under the capacity of supervisors and they can be given more incentives through preferring the company interests over their personal interests (Mulili and Wong 2011).

The governance is defined as a group of mechanisms and actions which guarantee the presence of good administration practices for the management group. This guarantees the presence of a balanced contractual relationship and monitoring standards on the execution of works and taking decisions in a form which maximize the organization value in the market (Saad 2010).

(Gibson 2003) defined the corporate governance mechanisms as "A group of controls and methods used in overcoming the problem of agency which occurs between the management and the shareholders". (Marn and Romuald 2012) stated that the governance was extracted from the agency theory in the organization because of the inflation in the volume of the organizations and the separation of the ownership from the shareholders or the owners and hence there must exist rules which organize the relationship between the parties which are interested in the performance of the organization.

Corporate governance consists of internal and external mechanisms (Wu, Lin et al. 2009) where the internal governance 
The Influence of Implementing the Internal Corporate Governance .....

Dr. Ehab Lotfy AbdElaal Abied \& Dr. Hassan Mahmoud Aly Khalil

mechanisms give the priority to the shareholders and they work in the board of directors to monitor the top management. Alternatively, the external corporate governance mechanisms monitor the behaviors of the managers and control them through legislations which include the suppliers, accountants, lawyers and the providers of the credit services and the professional institutes. The study by Marn and Romuald, 2012 recognized the following five main mechanisms for the governance: Board Size, formation of board of directors, review committee, status of the executive manager, the ownership framework where the board size and the ownership framework have a great influence on the company's performance. But other variables did not appear (Marn and Romuald 2012). (Aljifri and Moustafa 2007) stated that the governance mechanisms are a group of methods to overcome the problems in implementing and practicing the governance in the organizations. There is a semi-agreement between the organizations caring about the governing aspects (International Bank, Economical Cooperation Organization, The Special International Projects Center) and also the researchers in the scope of corporate governance where the governance mechanisms include the following: (Ministry of Investment, 2011), (Gibson 2003) (Wu, Lin et al. 2009) (Gibson, 2003), (Wu, Lin et al. 2009), (Marn and Romuald 2012).

\subsection{Board size:}

The board size attracted great attention in the corporate governance literature because it has an effective role on selecting the strategies. (Almajali, Alamro et al. 2012) study stated that the board of directors is considered an important factor for the success of the organization. If the board of directors is committed to the signed agreements, then the company's success ratios will be increased. Jensen, 1983 suggested that the effective size for the board is between seven and eight members ( $\operatorname{Rad} 2014)$. Whereas Reddy, Locke et al., 2008 see that the larger board size reduces the companies productivity because the communication 
The Influence of Implementing the Internal Corporate Governance .....

Dr. Ehab Lotfy AbdElaal Abied \& Dr. Hassan Mahmoud Aly Khalil

with the executive manager becomes more difficult when the councils become large and there are difficulties in taking the decisions which maximize the value (Reddy, Locke et al. 2008). Kajola, 2008 stated that increasing the number of the board of directors results in improving the monitoring but reduces the communications and increases the conflicts in decision-making (Kajola 2008). Kyereboach-Coleman, 2008 stated that a small number of the board of directors members improves the flow of communications with the organization which will also result in taking a better decision by the management (Kyereboah-Coleman 2008).

\subsection{Board Independence:}

To enable the board of directors to practice its role and to monitor the management when preparing the reports which achieve control for the executive managers, then the majority members of the board must be from outside because they can better monitor the management compared to the members from inside the organization ( $\mathrm{Lu} \mathrm{2016).}$

\subsection{CEO-Duality:}

The CEO-Duality means than one person plays the role of the executive manager and the head of board (Mwangi, Makau et al. 2014). Saad, 2010 points out that the effective corporate governance must guarantee that the selection of the executive managers and the new managers must be transparent and formal. To perform this, the organization must setup a special committee from the board of directors to guarantee the selection of the candidates with potentials, qualifications and required expertise (Saad 2010). There is CEO-Duality when the member of the board of directors occupy the position of the executive manager and head of the board (Ahmed Sheikh, Wang et al. 2013).

\subsection{Managerial Ownership:}

The managerial ownership provides a direct economic incentive for the managers to participate in the active monitoring which increases the risk, and the increase in the share of 
The Influence of Implementing the Internal Corporate Governance .....

Dr. Ehab Lotfy AbdElaal Abied \& Dr. Hassan Mahmoud Aly Khalil

ownership of the management can be an incentive to increase the performance (Mardnly, Mouselli et al. 2018). The laws of corporate governance specified the framework of the ownership including that the managers don't own shares a year before the start of appointing them in ministry of investment (Egyptian Companies Governing Rules).

\subsection{Institutional Ownership:}

This points to what is owned by the founders shareholders in terms of shares inside the company (Ogbeche 2006) where the founders investors play an important role in monitoring the management (Grassa, Chakroun et al. 2018).

\subsection{Audit Committee Independence:}

Audit Committee Independence represents an internal governance mechanism (Gill and Biger 2013). The audit committee consists of not less than three members of the board of non-executive directors. Its members must also include one expert in the financial and accounting affairs. In case of the nonavailability of the sufficient number of the non-executive board of directors members (Kyereboah-Coleman 2008).

\subsection{Audit Committee Meetings:}

Gill and Bigger, 2013 suppose that the periodical meetings for the audit committee work on the continuous auditing of the cash accounts which in return reduces its role in terms of the agency problems and the agency costs (Gill and Biger 2013).

\section{(2) Efficiency of Working Capital Management:}

In the financial literature, there is a common opinion concerning the importance of the working capital which includes the effective management of the working capital, planning and monitoring the liabilities and the current assets in a way which attracts extra investments in the current assets and prohibits the work in reducing the current assets to guarantee the fulfilling of the responsibilities (Raheman and Nasr 2007).

The efficiency of managing the working capital is one important objective in the short term, where managing the 
The Influence of Implementing the Internal Corporate Governance .....

Dr. Ehab Lotfy AbdElaal Abied \& Dr. Hassan Mahmoud Aly Khalil

working capital is considered a vital case in the financial management decision which can influence the liquidity and help to create a value for the company (Bagchi, Chakrabarti et al. 2012). The managing of working capital is an important function in the management of the companies to preserve the suitability, profitability, liquidity of the company (Kamau and Basweti 2013). Many researchers stated that both the cash conversion cycle and the current ratio are among the measures for the efficiency of the working capital as follows:

\subsection{The Cash Conversion Cycle (CCC):}

This period starts by paying for buying the raw materials for the sake of manufacturing the products and ends up with the collection of the due accounts linked to the process of selling the product. The cash conversion cycle is considered as the optimal measure for the efficient management of working capital (Vural, Sökmen et al. 2012).

\subsection{Current Ratio:}

The current ratio expresses the scope of reliance of the company on financing its current assets through the current liabilities (Fiador 2016).

\section{Literature Review:}

The study of (Achchuthan and Rajendran 2013) sees that a good implementation increases the efficiency of managing the working capital. (Gill and Shah 2012) study concluded that the corporate governance plays an important role in controlling the management of the working capital through formulating good policies and the CEO-Duality and board size help in preserving a suitable level of the working capital in the organization.

(Gill and Shah 2012) study concluded that the Board Size plays an important role in specifying the optimal ratio for the short term capitals required by the organization. Another study by (Jamalinesari and Soheili 2015) reached the conclusion that the efficiency of the management of collecting the accounts receivable increases by the reduction in board size. This is a 
The Influence of Implementing the Internal Corporate Governance .....

Dr. Ehab Lotfy AbdElaal Abied \& Dr. Hassan Mahmoud Aly Khalil

directly proportional statistical relationship between the board independence and the average period for collecting the accounts receivable and the level of cash in the organization.

The study by (Kamau and Basweti 2013) which was performed because there was no statistically significant relationship between the board size and the gathering of the executive manager position and the management efficiency of working capital. There is no statistical significant relationship between the board of director and the efficiency of the working capital.

(Ghazali and Manab 2013) study stated that the board of directors and the executive president are responsible for formulating the policies related to the management of cash, accounts receivable, buying the stock and maintenance, accounts payable and all other policies in the organization.

As for Gill \& Bigger,2013 study which looked into the influence of the corporate governance on the efficiency of managing the working capital of American manufacturing corporations. The study reached the conclusion that there is a large positive relationship between the CEO-Duality with the management of the accounts receivable and the management efficiency of the accounts payable, and a significant positive relationship between the CEO-duality and the efficiency of the conversion of the cash, where it was found that the board size has a significant negative relation with the cash conversion cycle and the ratio of transactions (Gill and Biger 2013).

Drobetz \& Gruninger, 2007 investigated the cash determinants for a comprehensive sample of 156 non-financial Swiss corporations between the years 1995 and 2004. They found a positive relationship between the CEO-Duality and the cash assets for the companies. The un-important relationship between the board size and the cash assets for the companies which means that the greater board size has no influence on the company's cash possessions (Drobetz and Grüninger 2007). 
The Influence of Implementing the Internal Corporate Governance .....

Dr. Ehab Lotfy AbdElaal Abied \& Dr. Hassan Mahmoud Aly Khalil

(Meshack 2015) study aimed at knowing the influence of the corporate governance indicators on the efficiency of the working capital in the industrial companies. The study showed the presence of an influence for the corporate governance indicators which are represented by the variables of board framework, internal accuracy, and the care by shareholders on the efficiency of managing the working capital variable. There is a positive relationship between the board framework and the internal accuracy with the efficiency of managing the working capital.

(Palombini and Nakamura 2012) study which took place in Brazil showed that there is no relationship between the ownership concentration ratio and the ratio of the board independency with the management of the working capital on the other hand. The management of the working capital was expressed through the cash conversion cycle and the period of preserving the stock and the period of paying back the accounts payable.

As for (Aghajari, Mousavi et al. 2015), it found the presence of an inverse statistically significant relationship between the institutional ownership and average period of collection.

(Ahmad, Ahmed et al. 2018) study confirmed that the increase in ownership of the executive presidents can reduce significantly the cash conversion cycle by $50.1 \%$ whereas the variation at $89.9 \%$ in the cash conversion cycle which is explained through the position of the executive president.

(Gill and Biger 2013) study showed that the audit committee independence works on improving the efficiency of managing the working capital through auditing the accounts receivable and payable and its stocks in the company.

(Goh 2009) study clarified the relationship between care given to the audit committees as one of the governance mechanisms and taking the correct actions in the internal auditing 
The Influence of Implementing the Internal Corporate Governance .....

Dr. Ehab Lotfy AbdElaal Abied \& Dr. Hassan Mahmoud Aly Khalil

which achieve an increase in profitability of the business organizations. The study showed the presence of a direct relationship between the decency, the audit committee independence and the potential of the company in correcting the monitoring system and improving the profitability. The availability of effective audit committees resulted in the quick discovery of the financial and accounting mistakes.

As for Fiador,2016 study, it reached the conclusion of presence of a negative influence for the internal mechanisms on the cash conversion cycle, stocktaking, due periods, payments periods. This implies that the management framework influence the efficiency of managing the working capital, Also appeared fixed properties such as work, size and profitability as influencing factors related to the efficient management of working capital (Fiador 2016).

(Wasiuzzaman and Arumugam 2013) showed that there is no statistical correlation between the board size and the independence of that board and the investment with the net working capital. And there is no statistical correlation between the number of the board meetings and the net working capital.

Moussawi et al, 2006 study collected data from the American general corporations during the periods from (1990 2014) to define the determinants of the working capital. The study reached that the type of industry and the growth of the company's sales in the future and the company size has a significant influence whereas the executive compensations and ownership of the board and ratio of external executive managers have a negative influence on the management efficiency of the companies' working capital. The study proposed that the performance of the working capital is better with the increasing of audit committee independence and increasing the executive compensation (Moussawi, LaPlante et al. 2006).

\section{After discussing the most important findings of review of literature, the following results can be concluded:}

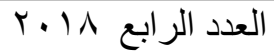

المجلد التاسع 
The Influence of Implementing the Internal Corporate Governance .....

Dr. Ehab Lotfy AbdElaal Abied \& Dr. Hassan Mahmoud Aly Khalil

- Dispute is still existing, concerning defining the nature of influence of the internal corporate governance mechanisms on the management efficiency of working capital where many studies show a positive influence between the corporate governance mechanisms and the efficiency of managing the working capital (Jamalinesari and Soheili 2015) (Gill and Biger 2013) (Meshack 2015). Many studies showed an inverse influence between the corporate governance and the efficiency of managing the working capital (Palombini and Nakamura 2012), (Aghajari, Mousavi et al. 2015), (Ahmad, Ahmed et al. 2018). Other studies showed Other studies showed that there is no relationship between the corporate governance mechanisms and the efficiency of managing the working capital (Kamau and Basweti 2013).

- Many of the studies concentrated the importance of implementing the internal governance mechanisms which helps in reducing the average time taken for collecting the indebted dues and formulating the policies related to cash management and the payment due accounts and improving the stock buying process and organizing the payment due accounts.

- Variations of the internal companies governance mechanisms from one study to another and from one country to another due to variations in samples of the companies governance in each country.

- Methods of measuring efficiency management working capital vary from one study to another with many variations of factors such as the nature of the sectors covered by the study.

\section{IV- Questions of the study:}

The study attempts to answer the following question: "What is the influence of implementing the internal corporate governance mechanisms (Board size, board independence, CEODuality, Managerial Ownership, Institutional Ownership, Audit 
The Influence of Implementing the Internal Corporate Governance .....

Dr. Ehab Lotfy AbdElaal Abied \& Dr. Hassan Mahmoud Aly Khalil

Committee Independence, Audit Committee Meetings) on the efficiency of managing the working capital. This question raises the following secondary questions:

- What is the influence of the internal corporate governance mechanisms on the cash conversion cycle?

- What is the influence of the internal corporate governance mechanisms on the current ratio?

\section{V- The Study Objectives:}

The main objective of this study is to know the influence of the internal governance mechanisms on the efficiency of managing the working capital. The secondary objective is to give suggestions for the companies listed in the Egyptian Stock Exchange to obtain the efficiency in managing the working capital through the best practices of the corporate governance. The objectives of the study are the following:

- Understanding the mechanisms of the internal corporate governance in the various sectors under implementation and whether there are differences between the governance mechanisms according to the type of the sector.

- Selecting the relationship between the influence of implementing the internal corporate governance and the efficiency of managing the working capital.

- Specifying the internal governance mechanisms which have more influence on the efficiency of managing the working capital variables.

- Providing a group of recommendations related to the importance of implementing the internal governance mechanisms in the Egyptian business environment to increase the efficiency of managing the working capital in the companies listed in the Egyptian Stock Exchange.

\section{VI- Study Hypotheses:}

The following assumptions are formulated: 
The Influence of Implementing the Internal Corporate Governance .....

Dr. Ehab Lotfy AbdElaal Abied \& Dr. Hassan Mahmoud Aly Khalil

1- There are no statistically significant differences for the internal corporate governance variables according to the sector type.

2- There is no moral influence for the internal corporate governance mechanisms on the cash conversion cycle.

3 - There is no moral influence for the internal corporate governance mechanisms on the current ratio.

\section{VII: Study Importance:}

4- This study is important because of the importance of the variables (mechanisms of the internal corporate governance, efficiency of managing the working capital) where many of the possible determinants for the efficiency management of the working capital haven't been discovered. "The mechanisms of the internal corporate governance" are considered one of these determinants where the research attempts to show the nature of this relationship in the companies listed in the Egyptian Stock Exchange. This research has the following practical and applied importance:

\section{(1) Scientific Importance:}

$1 / 1$ implementing the mechanisms of governance represents one of the modern managerial inputs in providing a suitable environment to practice the methods and actions related to monitoring the performance.

1/2 The study represents a conversion point towards implementing the internal governance mechanisms and its main principles on the organizations working in the Egyptian Stock Exchange and showing the influence on the efficiency of managing the working capital.

$1 / 3$ The study represents an attempt to close the scientific gap related to how to utilize implementing the internal governance mechanisms in providing the components of developing the efficiency management of the working capital. 
The Influence of Implementing the Internal Corporate Governance .....

Dr. Ehab Lotfy AbdElaal Abied \& Dr. Hassan Mahmoud Aly Khalil

1/4 The academic origin of the internal governance mechanisms and their suitability to the intellectual development in the scope of financial management.

\section{(2) Practical Importance:}

The importance of the study differs from what the researchers used in the scope of the governance studies and its applications on the organization where this study is considered as the first practical academic study in the Egyptian environment which covers the influence of implementing the internal governance mechanisms on developing the managerial efficiency of the working capital in the organizations working in the Egyptian Stock Exchange.

\section{VIII: Method of Study:}

In this part of the study, the researcher covers the study variables, methods of measuring them, study sample and population, source of information, statistical analysis method, study limitations as follows:

\section{(1) Study Variables and Method For Measuring Them:} follows:

The following table presents the study variables as 
The Influence of Implementing the Internal Corporate Governance .....

Dr. Ehab Lotfy AbdElaal Abied \& Dr. Hassan Mahmoud Aly Khalil

\begin{tabular}{|c|c|c|}
\hline $\begin{array}{l}\text { Variable } \\
\text { Type }\end{array}$ & Concept & Measure \\
\hline Dependent & Cash Conversion Cycle & $\begin{array}{l}\text { Average collection period }+ \text { Inventory } \\
\text { conversion period }- \text { Average payment period }\end{array}$ \\
\hline Dependent & Current Ratio & Current assets divided by current liabilities \\
\hline Independent & Board Size & The make-up of the board of directors \\
\hline Independent & Board Independence & $\begin{array}{l}\text { Ratio of Board Independence to total number } \\
\text { of board members }\end{array}$ \\
\hline Independent & CEO-Duality & $\begin{array}{l}\text { Allocate } 1 \text { if chairperson and CEO and } \\
\text { Allocate } 0 \text { if chairperson is not also CEO }\end{array}$ \\
\hline Independent & Managerial Ownership & $\begin{array}{l}\text { Ratio of shares owned by the managers } \\
\text { inside the company = Total shares owned by } \\
\text { the Managers + Company's shares as a } \\
\text { whole. }\end{array}$ \\
\hline Independent & Institutional Ownership & $\begin{array}{l}\text { Ratio of shares owned by the shareholders } \\
\text { inside the company = Total shares owned by } \\
\text { the shares owned by the shareholders } * \text { The } \\
\text { company's shares as a whole. }\end{array}$ \\
\hline Independent & Audit Committee & Virtual Variable: \\
\hline & Independence & $\begin{array}{l}\text { (1) If the audit committee members were } \\
\text { from the independent managers. } \\
\text { (0) Otherwise. }\end{array}$ \\
\hline Independent & $\begin{array}{l}\text { Audit } \\
\text { Meetings }\end{array}$ & $\begin{array}{l}\text { Based on the No of meeting; } 1-5 \text { has been } \\
\text { represented as } 1 ; 6-10 \text { has been represented } \\
\text { as } 2 ; 11-15 \text { has been represented as } 3 \text {. }\end{array}$ \\
\hline Control & Firm Size & The total log of average assets \\
\hline Control & Firm Age & the organization life time \\
\hline
\end{tabular}

Source: Prepared by the Researcher.

\section{(2) Population and Study Sample:}

The study population covers all the companies listed in the Egyptian Stock Exchange which are 222 companies during the year 2005. The researcher selected a control sample because of the non-availability of all the information related to the corporate governance for all the companies registered in the Egyptian Stock Exchange. Consequently, companies which contained the internal corporate governance information during this period were selected. The study is limited to 41 companies of the companies working in the Egyptian Stock Exchange and which fulfilled the conditions for availability of information mechanisms for the internal corporate governance for at least 
The Influence of Implementing the Internal Corporate Governance .....

Dr. Ehab Lotfy AbdElaal Abied \& Dr. Hassan Mahmoud Aly Khalil

three years. These companies belong to the following four sectors: Food \& beverage, Real Estate, Industrial Goods \& Services \& Automobiles and Construction \& Materials.

\section{(3) Source of Data:}

The study depends on the secondary information through the references and the scientific periodicals which covered the relationship between the internal mechanisms for the corporate governance and the management efficiency of working capital. Also, from the yearly published information about the companies covered by the study.

\section{(4) Methods of Statistical Analysis:}

In the light of the research assumptions and its objectives the researcher used the following statistical methods:

4.1 Statistical Description of Data: This is represented in the repetitive, relative and double distribution; and on the Arithmetic Mean and the Standard Error and the level of Confidence at $95 \%$.

4.2 One-Way Analysis of Variance (Anova).

4.3 Chi Square Test.

4.4 Kolmogorov-Smirnov Test.

4.5 Balanced Panel Data Sample.

\section{(5) The Study Limitations:}

5.1 The study is limited to the internal mechanisms for the governance of the following companies.

5.2 This study is limited to 41 companies from the large companies working in the Egyptian stock exchange market and which belong to the following four sectors: Food \& beverage, Real Estate, Industrial Goods \& Services \& Automobiles and Construction \& materials.

5.3 The study extracted all the financial services sector companies and the banks sector because of the nature of the applied governance systems in those sectors and the rise in the volume of investments in these sectors compared with others. This is done after setting aside the 
The Influence of Implementing the Internal Corporate Governance .....

Dr. Ehab Lotfy AbdElaal Abied \& Dr. Hassan Mahmoud Aly Khalil

petrol and gas sectors and the health care sector companies because of the non-availability of information specific to the governance mechanisms.

\section{IX: Field Study Results:}

The researcher covered the research results and testing the validity of the assumptions as follows:

\section{(1) Testing the validity of the first study Assumption:}

To test the validity of the first assumption stating "There is no statistically significant differences for the corporate governance variables according to the type of sector" where the researcher used the following statistical methods:

- Statistical description of Data which is represented in the repetitive, relative double distribution and the Arithmetic Mean and the Standard Error and the Level of Confidence for the Average at $95 \%$ confidence level.

- The One-Way Analysis of Variance (Anova): This test aims at comparison between the sectors with each other followed by Tukey test for multi-comparison.

- Chi Square Test: To explain whether there is a correlation between the two variables or not.

4.6 The Kolmogorov-Smirnov (KS) where this test was used as an alternative to Chi square test in case of the incompletion of the Chi Square test.

The following is a presentation of the results of the validity of the first study's assumption. 


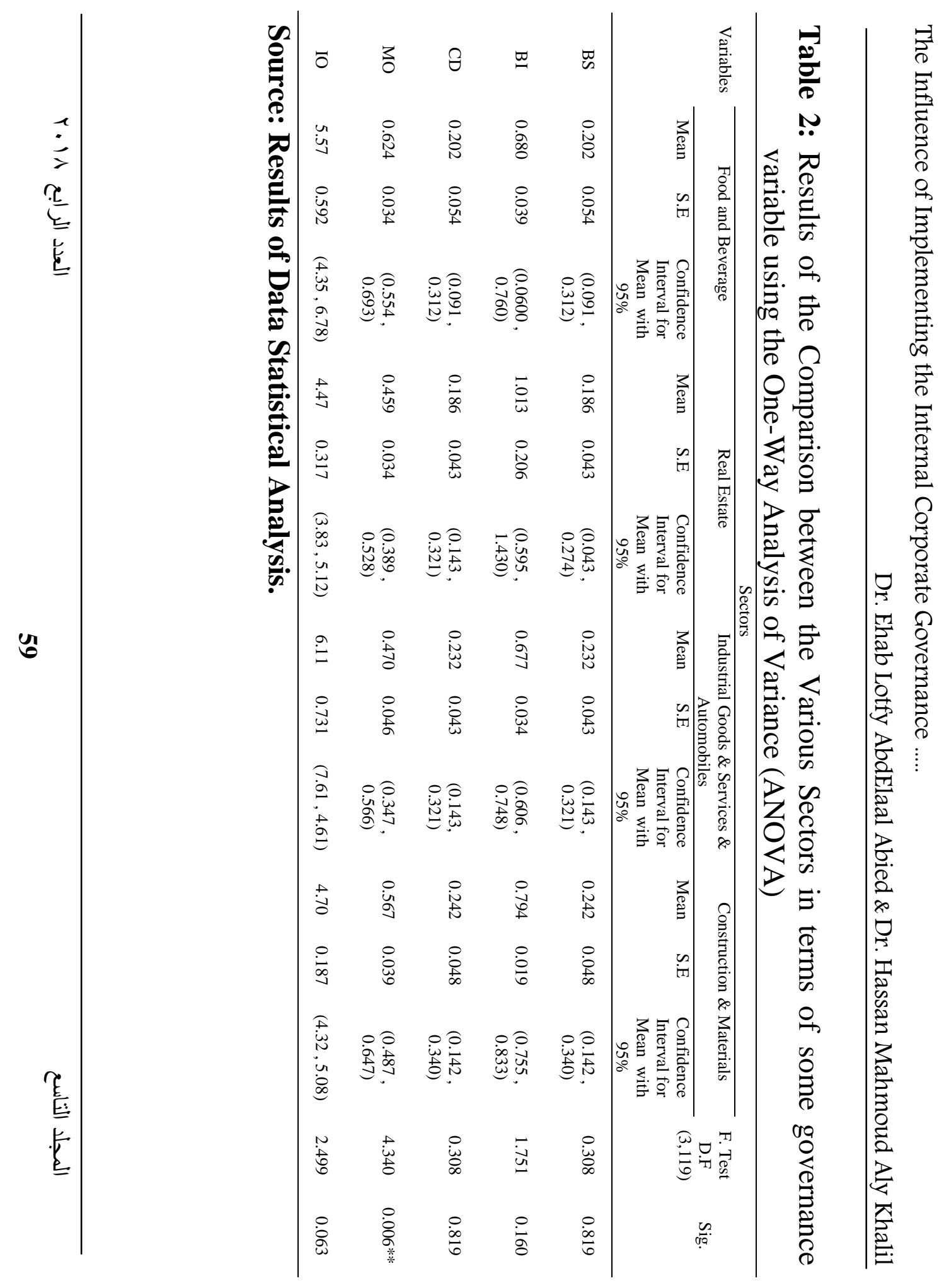


The Influence of Implementing the Internal Corporate Governance .....

Dr. Ehab Lotfy AbdElaal Abied \& Dr. Hassan Mahmoud Aly Khalil

Table 3: Results of Toki Test for Multi-Comparisons between various sectors according to the institutional ownership Toki Test for Multi-Comparisons based on the Institutional

Variables Ownership

$\begin{array}{lccc}\text { Food and } & \text { Real } & \text { Industrial Goods \& } & \text { Construction } \\ \text { Beverage } & \text { Estate } & \text { Services \& } & \text { \& Materials }\end{array}$

Food and Beverage

$0.164^{*}$

Automobiles

Real Estate

$0.153^{*}$

0.011

0.056

$-$

$\begin{array}{ll}- & 0.095\end{array}$

Industrial Goods \&

Services \&

Automobiles

Construction \& Materials

\section{Source: Results of Data Statistical Analysis.}

(1) Points at the difference between averages of the two sectors. * Points at the significance differences between the averages of the two groups.

The results shown in Table (3) confirmed the presence of statistically significant results between the various sectors in terms of the availability of the institutional ownership where the value of (F Calculated Test $=4.34)$ which confirms its statistical significance at the level of (0.01). By performing Tukey Test for multi-comparisons it became clear that these differences lie between the results of the food and beverage sector with each of the Real Estate and Industrial Goods \& Services \& Automobiles sectors. The statistical description confirms that these differences are in favor of the results of the Food \& Beverage sector. As for the other remaining variables, the results confirmed that there are no statistically significant differences between any of the other sectors. This was confirmed by (F-Test) which did not reach the limit which makes one of them at least (0.05) level. The following Table(4) studies the results of the variations between the four sectors with each of the CEO-Duality and the audit committee independence.

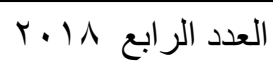


The Influence of Implementing the Internal Corporate Governance .....

Dr. Ehab Lotfy AbdElaal Abied \& Dr. Hassan Mahmoud Aly Khalil

Table (4): The Results of multi-variants between various sectors based on Audit Committee Independence and Role Duality

\begin{tabular}{|c|c|c|c|c|}
\hline \multirow[t]{2}{*}{ Tests \& Sectors } & \multicolumn{2}{|c|}{$\begin{array}{c}\text { Chi Square Test for } \\
\text { variations According to } \\
\text { Role Duality }\end{array}$} & \multicolumn{2}{|c|}{$\begin{array}{c}\text { (KS) test for variations } \\
\text { According to Audit Committee } \\
\text { independence }\end{array}$} \\
\hline & 0 & 1 & 0 & 1 \\
\hline \multirow[t]{2}{*}{ Food and Beverage } & 14 & 16 & 24 & 6 \\
\hline & 29.8 & 21.1 & 21.6 & 50.0 \\
\hline \multirow[t]{2}{*}{ Real Estate } & 12 & 24 & 30 & 6 \\
\hline & 25.5 & 31.6 & 27.0 & 50.0 \\
\hline Industrial Goods \& & 4 & 23 & 27 & - \\
\hline Services \& & 8.5 & 30.3 & 24.3 & - \\
\hline \multicolumn{5}{|l|}{ Automobiles } \\
\hline Construction \& & 17 & 13 & 30 & - \\
\hline Materials & 36.2 & 17.1 & 27.0 & - \\
\hline $\mathrm{K}^{2}$ & \multicolumn{2}{|c|}{11.859} & \multicolumn{2}{|c|}{ - } \\
\hline K.S & \multicolumn{2}{|c|}{-} & \multicolumn{2}{|c|}{1.690} \\
\hline D.F & \multicolumn{2}{|c|}{3} & \multicolumn{2}{|c|}{-} \\
\hline Sig. & \multicolumn{2}{|c|}{0.008} & \multicolumn{2}{|c|}{0.007} \\
\hline
\end{tabular}

Source: Results of Data Statistical Analysis.

Table (4) results showed the existence of variations between the sectors concerning the existence of CEO-duality where the value of Chi-square test $=11.859$ which in turn confirms its statistical significance at the $(0.01)$ level. The relative distribution confirmed the distinction of the sectors Real Estate and Industrial Goods \& Services \& Automobiles compared to each of the Food \& beverage and Construction \& Materials sectors.

The results also confirmed the existence of variations between the sectors concerning the audit committee independence where the value of The Kolmogorov-Smirnov Test. The Calculated K.S. Test $=1.690$ ) which confirms its statistical difference at (0.01) significance level. The relative distribution confirmed the availability of the audit committee is limited to both Food \& Beverage and Real Estate sectors; 
The Influence of Implementing the Internal Corporate Governance .....

Dr. Ehab Lotfy AbdElaal Abied \& Dr. Hassan Mahmoud Aly Khalil

whereas it does not exist in each of the Industrial Goods \& Services \& Automobiles and Construction \& Materials sections at all. level of:

Hence, we can accept the validity of the assumption at the

Board Size; Board Independence; Managerial Ownership; Audit Committee Meetings.

We can refuse the validity of the assumption at the level of:

Institutional Ownership; CEO-Duality; Audit Committee Independence.

Hence, we can partially accept the first assumption for the study.

(2) Selecting the validity of the Study's Second \& Third Assumptions:

To test the second and third assumption for the study:

- There is no moral effect for the internal corporate governance on the Cash Conversion Cycle.

- There is no moral effect for the internal corporate governance mechanisms on the Current Ratio.

The researcher used the Balanced Panel Data. The following is a presentation of the results for testing the validity of the second and third assumptions:

The researcher performed a group of attempts to reach the best combination of the governance indicators (independent variables) which can explain the variations in both the Cash Conversion Cycle and Current Ratio. 


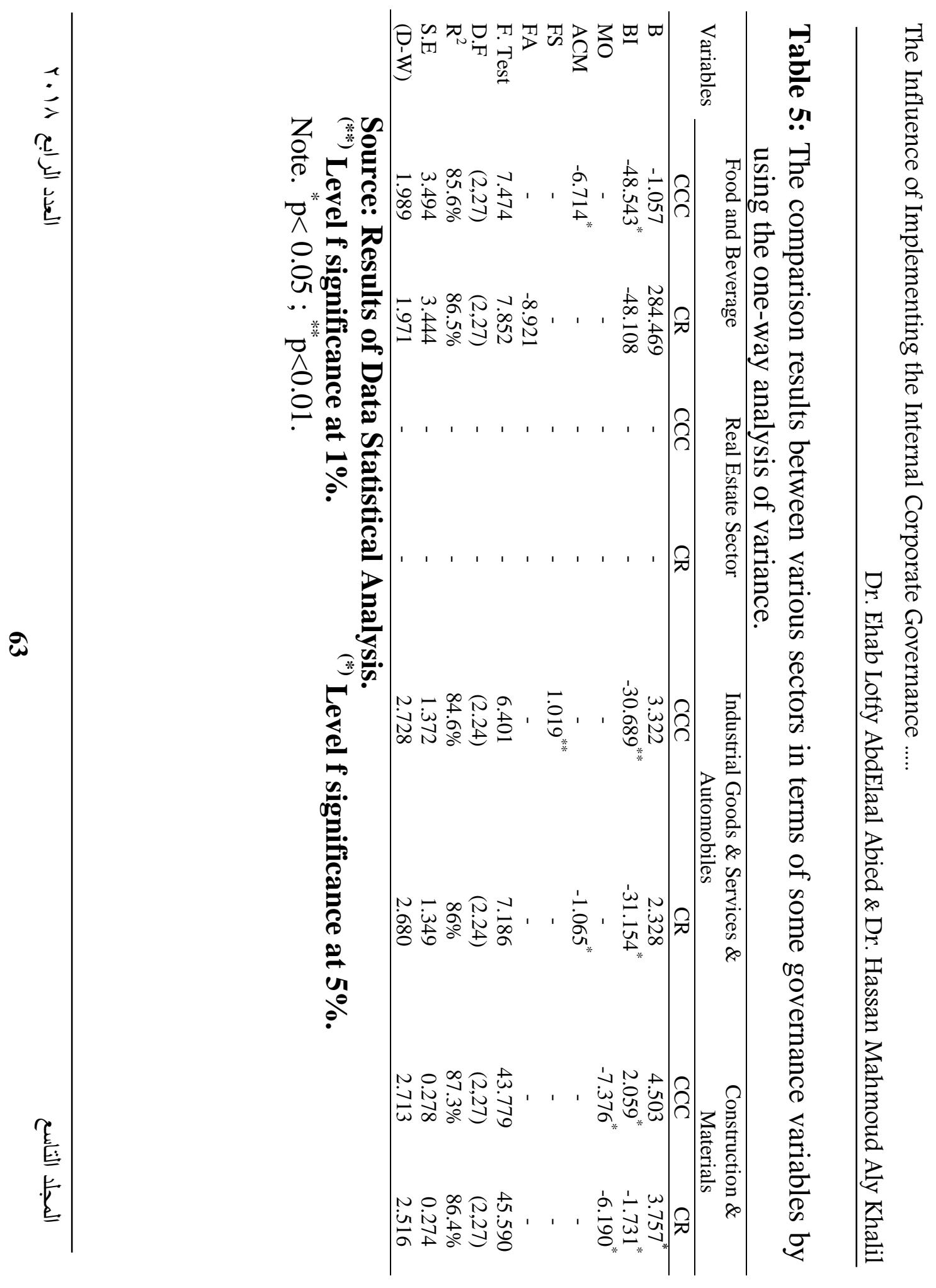


The Influence of Implementing the Internal Corporate Governance .....

Dr. Ehab Lotfy AbdElaal Abied \& Dr. Hassan Mahmoud Aly Khalil

\section{(1) Results related to the Food and Beverage Sector:}

- The previous table results confirmed the significance of the estimated sample where the value of $(\mathrm{F}$ Calculated Test $=$ 7.474) which confirms its statistical significance at $(0.01)$ level with Degrees of Freedom $(2,27)$ these variables explain the variations which occur to the Cash Conversion Cycle $\left(\mathrm{R}^{2}=85.6 \%\right.$ ) are: Board Independence (inverse influence); Audit Committee Meetings (inverse influence) ordered according to the relative importance of the variable in the estimated sample. As for the serial correlation test (DurbinWatson) the value of the Durbin-Watson Test $(\mathrm{D}-\mathrm{W}=1.989)$ which is an ideal value where it achieves $(\mathrm{dU}<\mathrm{D} . \mathrm{W}<2)$ which in turn confirms that the sample does not suffer from the problem of Serial Correlation at all.

- The results in previous table confirmed the sample's significance where the value of (F Calculated $=7.852)$ which confirms its statistical significance at (0.01) significance; Degrees of Freedom $(2,27)$. The results confirmed that the explained variables in the sample which explain the changes which occur on Current Ratio $\left(\mathrm{R}^{2}=86.5 \%\right)$ is: Board Independence (inverse influence); Company's Age (inversed influence) ordered according to the relative importance for the variable in the estimated sample. As for (Durbin-Watson) Serial Correlation Test, the value of the Durban-Watson (D$\mathrm{W}=1.971$ ) which is an ideal value where it achieves $(\mathrm{dL}<\mathrm{D} . \mathrm{W}<2)$ which in turn confirms that the sample does not suffer from the problem of Serial Correlation at all. (2)

\section{Results Related to Real Estate Sector:}

- The researcher performed a group of attempts to achieve some governance pointers (independent variables) or a sole pointer which explains the changes in the Cash Conversion Cycle but this has never been achieved at all.

- The researcher performed a group of attempts to achieve some governance pointers (independent variables) or one

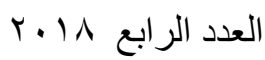

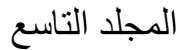


The Influence of Implementing the Internal Corporate Governance .....

Dr. Ehab Lotfy AbdElaal Abied \& Dr. Hassan Mahmoud Aly Khalil

pointer at least which explains the changes in the Current Ratio but this has never been achieved.

\section{(3) Results Related to Industrial Goods \& Services \& Automobiles Sector:}

- The results in the previous table confirmed the sample's significance where the value of Calculated $F=6,401$ which confirms its statistical significance at (0.01) level; with Degrees of Freedom $(2,24)$. The results confirmed the variables which explain the changes occurring on the Cash Conversion Cycle $\left(\mathrm{R}^{2}=84.6 \%\right)$ are: The Natural Logarithm for the board size (direct influence); Board Independence (inverse influence) ordered according to the relative importance for the variable in the estimated sample. The value of the DurbinWatson test $(\mathrm{D}-\mathrm{W}=2.728)$ which achieves $(4-\mathrm{du}<\mathrm{D} . \mathrm{W}<4-\mathrm{dL})$ and hence this does not confirm that the sample suffers from the problem of Serial Correlation.

- The results of previous table confirmed the significance of the sample where the (Calculated F Test $=7.186$ ) which confirms its statistical significance at (0.01) level with Degrees of Freedom $(2,24)$. The results confirmed the variables which explain the changes which occurred to the Current Ratio $\left(\mathrm{R}^{2}=86.0 \%\right)$ are: Audit Committee Meetings (inverse influence); Board Independence (inverse influence) ordered according to the relative importance for the variable. As for the serial correlation test (Durbin-Watson), the value of the Durbin-Watson (D-W=2.680) where this achieves (4$\mathrm{du}<\mathrm{D}$. W $<4-\mathrm{dL}$ ) and consequently we can't confirm that the sample suffers from the problem of Serial Correlation.

\section{(4) Results Specific to Construction \& materials Sector:}

- The previous table's results showed the significance of the sample where the F calculated value $=43.779$ which confirms its statistical significance at (0.01) significance level with Degrees of Freedom $(2,27)$. The results also confirmed the

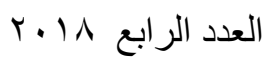

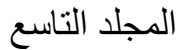


The Influence of Implementing the Internal Corporate Governance .....

Dr. Ehab Lotfy AbdElaal Abied \& Dr. Hassan Mahmoud Aly Khalil

variables which explain the changes occurring on the Cash Conversion Cycle $\left(\mathrm{R}^{2}=87.3 \%\right)$ are: Board Independence (direct influence); Institutional Ownership (inverse influence) ordered according to the relative importance for the presence of this variable in the estimated sample. As for the Serial Correlation test (Durbin-Watson) the value of the DurbinWatson Test $(\mathrm{D}-\mathrm{W}=2.713)$ where it achieves $(4-\mathrm{du}<\mathrm{D} . \mathrm{W}<4-$ dL) and consequently we don't confirm that the sample suffers from the problem of Serial Correlation.

- The results in the previous table confirm the sample significance where the value of Calculated $\mathrm{F}=45.590)$ which confirms its statistical significance at (0.01) level with Degrees of Freedom $=2,27$ ). The results also confirmed the variables which explains the changes which occur on the Current Ratio $\left(\mathrm{R}^{2}=86.4 \%\right)$ are: Board Independence (Inverse influence); Institutional Ownership (inverse influence) ordered according to the relative importance for the variable in the sample. As for the serial correlation (Durbin Watson) the value of the Durban-Watson ( $\mathrm{D}-\mathrm{W}=2.516)$ which achieves $(4-\mathrm{du}<\mathrm{D} . \mathrm{W}<\mathrm{dL})$ and consequently we can't confirm that the sample suffers from the problem of Serial Correlation. We can accept the validity of the third assumption for the results of the sixth sector only and reject it for the results of remaining sectors and consequently we can accept the relative validity of the second assumption which is inclined towards a rejection.

\section{X: Conclusions:}

This research aimed at discovering the influence of implementing the internal corporate governance on the efficiency of managing the working capital for the companies listed in the Egyptian Stock Exchange. The results showed the following:

1-There are no differences with statistical significance for the internal corporate governance variable according to the type of the sector on the level of the governance mechanism of the

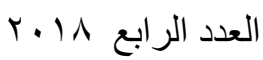

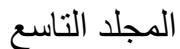


The Influence of Implementing the Internal Corporate Governance .....

Dr. Ehab Lotfy AbdElaal Abied \& Dr. Hassan Mahmoud Aly Khalil

following companies Board Size, Board Independence, managerial ownership, audit committee meetings.

2-There are statistical significant differences for the internal corporate governance according to type of the sector at the level of the governance mechanisms for the following companies i.e. Institutional Ownership, CEO-Duality, audit committee independence.

3 - There is an inverse significant influence for the following internal corporate governance mechanisms: Board Independence, Audit Committee Meetings on Cash Conversion Cycle in the Food \& Beverage Sector where these variables explain $85.6 \%$ of the changes occurring on the Cash Conversion Cycle and that $13.4 \%$ refer to other variables which are covered by the study. The researcher sees that the main purpose of the councils is monitoring and the extent of the effective monitoring is directly linked with extent of councils independency in addition to the periodical meetings for the audit committee to examine the policies suitable for the accounts which are due to payment and managing the stock which has a positive influence on reducing the cash cycle in the company. This study matches the results of each of (Palombini and Nakamura 2012) (Wasiuzzaman and Arumugam 2013) and (Gill and Biger 2013).

4- There is no statistical significance for the internal corporate governance mechanisms on the Cash Conversion Cycle in the Real Estate Sector. The results of this study coincide with the result of (Kamau and Basweti 2013) (Wasiuzzaman and Arumugam 2013) and (Aghajari, Mousavi et al. 2015).

5-There is a significant influence for the following internal corporate governance mechanisms i.e. board independence (inverse influence) and the monitoring variable i.e. company size (direct influence) on the Cash Conversion Cycle in the Industrial Goods \& Services \& Automobiles where these variables explain $84.6 \%$ of the variables which occur on cash

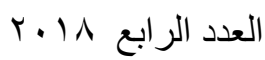

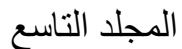


The Influence of Implementing the Internal Corporate Governance .....

Dr. Ehab Lotfy AbdElaal Abied \& Dr. Hassan Mahmoud Aly Khalil

conversion cycle and that $15.6 \%$ refer to other variables which are not covered by the study. The researcher sees that this is due to the increase in company size followed by an increase in the size of its works in the light of board independence which may lead to un-suitable policies concerning the accounts receivable and the accounts payable and the stock management which have a negative influence on the cash conversion cycle where the policy of preserving high cash balances may lead the management to limit the risk. The results of this study coincide with the results of the studies: (Palombini and Nakamura 2012) (Marn and Romuald 2012) and (Wasiuzzaman and Arumugam 2013).

6- There a significant influence for the following internal corporate governance mechanisms: Board independence (direct influence) and the institutional ownership (inverse influence) on the cash conversion cycle in Construction \& Materials sector. These variables explain $87.3 \%$ of changes which occur on the cash conversion cycle and that $12.7 \%$ refers to other variables which are not covered by this study. The researcher supposes that this is referred to the institutional ownership which plays an important role in the struggle between the managers and the shareholders and then reducing the costs of the agency where the more the institutional ownership, the higher are the collection efforts to reduce the collection period which is reflected in reducing the cash cycle which is the subject of this study. The positive correlation between the board independence and the cash cycle is due to the attempt to keep the liquidity assets inside the organizations which is reflected in the increase in the cash cycle in the organization. This study matches the results of the following studies: (Palombini and Nakamura 2012), (Wasiuzzaman and Arumugam 2013) and (Aghajari, Mousavi et al. 2015).

7-There is an inverse significant correlation for the following internal corporate governance mechanisms: Board

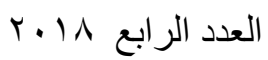

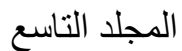


The Influence of Implementing the Internal Corporate Governance .....

Dr. Ehab Lotfy AbdElaal Abied \& Dr. Hassan Mahmoud Aly Khalil

Independence and company age on the Current Ratio in the food and beverage sector. These variables explain $86.5 \%$ of the changes which occur on the cash conversion cycle. This is because of following policies for managing the current assets and the current liabilities in the companies which keep the required rates of transactions according to what is followed inside the organization for some time period. The results of this study match with the following studies: (Palombini and Nakamura 2012) and (Wasiuzzaman and Arumugam 2013).

8-There is a significant correlation for the mechanisms of the internal corporate governance on the Current Ratio in Real Estate sector. This study's results match those from following studies: (Kamau and Basweti 2013), (Wasiuzzaman and Arumugam 2013) and (Aghajari, Mousavi et al. 2015).

9- There is a significant influence for the following mechanisms of the internal corporate governance: audit committee meetings (positive influence) and board independence (inverse influence) on the current ratio in Industrial Goods \& Services $\&$ Automobiles. These variables explain $86 \%$ of the changes occurring on the cash conversion cycle and $14 \%$ refer to other variables which are not covered by this study. The researcher sees that the main purpose of the Councils is monitoring and the extent of the effective monitoring is correlated directly with degree of independency of the councils and the periodical meetings for the audit committee which is reflected on the extent of suitability between the current assets and the current liabilities inside the company (extent of liquidity inside the company). This study's results coincide with the results from the following studies: (Palombini and Nakamura 2012) and (Wasiuzzaman and Arumugam 2013).

10- There is an inverse significant influence for the following internal corporate governance mechanisms: board independence, institutional ownership on the Current Ratio in the construction \& materials sector. These variables explain

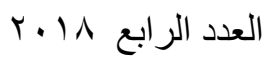

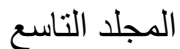


The Influence of Implementing the Internal Corporate Governance .....

Dr. Ehab Lotfy AbdElaal Abied \& Dr. Hassan Mahmoud Aly Khalil

$86.4 \%$ of the changes which occur on the Cash Conversion Cycle and that $13.6 \%$ refer to other variables which are not covered by this study. This is due to the suitable policies concerning the investments in the current assets and current liabilities and following policies which reflect preserving cash assets to limit the risk. This study matches with the following studies: (Palombini and Nakamura 2012) and (Wasiuzzaman and Arumugam 2013). Whereas the inverse influence differs with the study by (Belev 2003) (Aghajari, Mousavi et al. 2015).

\section{XI: Recommendations:}

This study reached the following recommendations:

- Importance of realization and awareness by those who are responsible for the companies in the Egyptian Stock Exchange by applying the mechanisms of the internal governance because of their role in increasing the efficiency of managing the working capital in the companies and then improving the company's performance in the long term.

- Imposing penalties in case of non-commitment of the companies to the requirements of declaration and transparency about the results and acts, and applying rules of the financial monitoring institute to guarantee providing information for the subscribed members and helping to take the continuation decision or the withdrawal from the company.

- Providing sufficient support for the internal audit on the company's activities to guarantee achieving good practices for corporate governance and ensuring matching with the international standards for the governance rules.

- The importance of utilizing from implementing the corporate governance mechanisms in developing the performance in the non-profit seeking organizations because these are organizations which don't get enough attention by the academics.

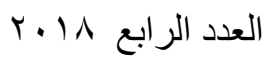

المجلد التاسع 
The Influence of Implementing the Internal Corporate Governance .....

Dr. Ehab Lotfy AbdElaal Abied \& Dr. Hassan Mahmoud Aly Khalil

\section{Future Studies:}

- Studying the relationship between the internal corporate governance mechanisms and the various performance indicators such as profitability, return, risk and social responsibility indicators.

- Checking and searching the integration and correlation between the internal corporate governance mechanisms and the sample of balanced measure of the performance.

- Study the principles of managing and monitoring the risks of the activities in the companies registered in the Egyptian Stock Exchange and the international standards for the financial reports so as to identify the scope of their correlation with the principles and rules of the governance.

- The role of the electronic information systems in activating the governance mechanisms in the organizations working in the Egyptian Stock Exchange.

- The mutual correlation between implementing the governance mechanisms and achieving the comprehensive quality in the companies listed in the Egyptian Stock Exchange. 
The Influence of Implementing the Internal Corporate Governance .....

Dr. Ehab Lotfy AbdElaal Abied \& Dr. Hassan Mahmoud Aly Khalil

\section{References:}

Achchuthan, S. and K. Rajendran (2013). "Corporate governance practices and working capital management efficiency: special reference to listed manufacturing companies in Sri Lanka."

Aghajari, M., et al. (2015). "Examining the Effect of Corporate Governance Mechanisms on Working Capital Management Efficiency of Corporations Accepted In Tehran Stock Exchange." International Journal of Review in Life Science 5(8): 63-73.

Ahmad, B., et al. (2018). "Working Capital Management Efficiency and Corporate Governance in Manufacturing Sector of Pakistan." European Online Journal of Natural and Social Sciences 7(1): pp. 67-86.

Ahmed Sheikh, N., et al. (2013). "The impact of internal attributes of corporate governance on firm performance: evidence from Pakistan." International Journal of Commerce and Management 23(1): 38-55.

Aljifri, K. and M. Moustafa (2007). "The impact of corporate governance mechanisms on the performance of UAE firms: an empirical analysis." Journal of Economic and Administrative Sciences 23(2): 71-93.

Almajali, A. Y., et al. (2012). "Factors affecting the financial performance of Jordanian insurance companies listed at Amman Stock Exchange." Journal of Management research 4(2): 266-289.

Bagchi, B., et al. (2012). "Influence of working capital management on profitability: a study on Indian FMCG companies." International Journal of Business and Management 7(22): 1.

elev, B. (2003). "Institutional investors in Bulgarian corporate governance reform: obstacles or facilitators?" Journal of World Business 38(4): 361-374.

Directory of rules and standards of governance of the companies in Arab Republic of Egypt, The Egyptian Managers Center, Ministry of Investment, 2011.

Dittmar, A. and J. Mahrt-Smith (2007). "Corporate governance and the value of cash holdings." Journal of financial economics 83(3): 599634.

Drobetz, W. and M. C. Grüninger (2007). "Corporate cash holdings: Evidence from Switzerland." Financial Markets and Portfolio Management 21(3): 293-324. 
The Influence of Implementing the Internal Corporate Governance .....

Dr. Ehab Lotfy AbdElaal Abied \& Dr. Hassan Mahmoud Aly Khalil

Fiador, V. (2016). "Does corporate governance influence the efficiency of working capital management of listed firms: Evidence from Ghana." African Journal of Economic and Management Studies 7(4): 482-496.

Ghazali, Z. and N. A. Manab (2013). "The effect of Malaysian Code of Corporate Governance (MCCG) implementation to companies' performances." Journal of Accounting, Finance and Economics 3(2): 43-52.

Gibson, M. S. (2003). "Is corporate governance ineffective in emerging markets?" Journal of financial and quantitative analysis 38(1): 231250.

Gill, A. and C. Shah (2012). "Determinants of corporate cash holdings: Evidence from Canada." International Journal of Economics and Finance 4(1): 70.

Gill, A. S. and N. Biger (2013). "The impact of corporate governance on working capital management efficiency of American manufacturing firms." Managerial Finance 39(2): 116-132.

Goh, B. W. (2009). "Audit committees, boards of directors, and remediation of material weaknesses in internal control." Contemporary Accounting Research 26(2): 549-579.

Grassa, R., et al. (2018). "Corporate governance and Islamic banks' products and services disclosure." Accounting Research Journal 31(1): 75-89.

Jamalinesari, S. and H. Soheili (2015). "The relationship between the efficiency of working capital management companies and corporate rule in Tehran Stock Exchange." Procedia-Social and Behavioral Sciences 205: 499-504.

Kajola, S. O. (2008). "Corporate governance and firm performance: The case of Nigerian listed firms." European journal of economics, finance and administrative sciences 14(14): 16-28.

Kamau, S. M. and K. A. Basweti (2013). "The relationship between corporate governance and working capital management efficiency of firms listed at the Nairobi securities exchange." Research Journal of Finance and Accounting 4(19): 190-199.

Kavulya, P. W. (2012). The effects of corporate governance on Savings and Credit Co-Operatives (Saccos) financial performance in Kenya.

Kyereboah-Coleman, A. (2008). "Corporate governance and firm performance in Africa: A dynamic panel data analysis." Studies in Economics and Econometrics 32(2): 1-24. 
The Influence of Implementing the Internal Corporate Governance .....

Dr. Ehab Lotfy AbdElaal Abied \& Dr. Hassan Mahmoud Aly Khalil

Lu, W. (2016). "An Exploration of the Associations among Corporate Sustainability Performance, Corporate Governance, and Corporate Financial Performance."

Mardnly, Z., et al. (2018). "Corporate governance and firm performance: an empirical evidence from Syria." International Journal of Islamic and Middle Eastern Finance and Management 11(4): 591-607.

Marn, J. T. K. and D. F. Romuald (2012). "The impact of corporate governance mechanism and corporate performance: A study of listed companies in Malaysia." Journal for the advancement of science \& arts 3(1): 31-45.

Meshack, S. N. (2015). Influence of corporate governance practices on working capital efficiency of manufacturing firms in Nairobi County.

Moussawi, R., et al. (2006). "Corporate working capital management: determinants and consequences." Philadelphia: University of Pennsylvania.

Mulili, B. M. and P. Wong (2011). "Corporate governance practices in developing countries: The case for Kenya." International journal of business administration 2(1): 14 .

Mwangi, L. W., et al. (2014). "Effects of working capital management on performance of non-financial companies listed in NSE, Kenya." European journal of business and management 6(11): 195-205.

Ogbeche, G. (2006). "Environmental dynamism, capital structure and performance: A theoretical integration and empirical test." Strategic Management Journal 12: 1-15.

Palombini, N. V. N. and W. T. Nakamura (2012). "Key factors in working capital management in the Brazilian market." Revista de Administração de Empresas 52(1): 55-69.

Rad, S. A. (2014). "The relationship between corporate governance practices and cost of capital in large listed companies of New Zealand and Singapore." Unpublished doctoral thesis, University of Waikito, New Zealand.

Raheman, A. and M. Nasr (2007). "Working capital management and profitability-case of Pakistani firms." International review of business research papers 3(1): 279-300.

Reddy, K., et al. (2008). "Corporate governance practices of small cap companies and their financial performance: an empirical study in New Zealand." International Journal of Business Governance and Ethics 4(1): 51-78. 
The Influence of Implementing the Internal Corporate Governance .....

Dr. Ehab Lotfy AbdElaal Abied \& Dr. Hassan Mahmoud Aly Khalil

Saad, N. M. (2010). "Corporate governance compliance and the effects to capital structure in Malaysia." International Journal of Economics and Finance 2(1): 105-114.

Vural, G., et al. (2012). "Affects of working capital management on firm's performance: evidence from Turkey." International Journal of Economics and Financial Issues 2(4): 488-495.

Wasiuzzaman, S. and V. C. Arumugam (2013). "Determinants of Working Capital Investment: A Study of Malaysian PublicListed Firms." Australasian Accounting, Business and Finance Journal 7(2): 6383.

Wu, M.-C., et al. (2009). "The effects of corporate governance on firm performance." Changua: National Changua University of Eductaion. 